\title{
Semitic Language
}

National Cancer Institute

\section{Source}

National Cancer Institute. Semitic Language. NCI Thesaurus. Code C160966.

A branch of the Afroasiatic language family originating in the Middle East that is spoken across much of Western Asia, North Africa and the Horn of Africa. 